\title{
The HLA linked iron loading gene in an Afrikaner population
}

\author{
T E MEYER*, D BALLOT*, T H BOTHWELL*, A GREEN*, \\ D P DERMAN*, R D BAYNES*, T JENKINS,+ P L JOOSTE \\ E D DU TOIT\&, AND P JACOBS\|
}

From *the MRC Iron and Red Cell Metabolism Unit, Department of Medicine, University of the $\overrightarrow{\vec{\omega}}$ Witwatersrand, Johannesburg; $+M R C$ Human Ecogenetics Research Unit, Department of Human Genetics $\stackrel{\circ}{S}$ School of Pathology, South African Institute for Medical Research, University of the Witwatersrand $\bar{\Omega}^{\circ}$ Johannesburg; $¥ M R C$ National Research Institute for Nutritional Diseases, Tygerberg; \$Provinciaћ Laboratory for Tissue Immunology, Cape Town; and \|Department of Haematology, University of Cape $e_{\sigma}^{+}$ Town, Observatory, South Africa.

SUMMARY The serum ferritin concentration was used as a screening test to identify the presence of iron overload in 599 Afrikaans subjects (300 males and 299 females) living in the South Westernc Cape, South Africa. Seventeen of the males with concentrations greater than $400 \mu \mathrm{g} / \mathrm{l}$ were reevaluated three and five years later. Serum ferritin concentrations were measured again and further diagnostic procedures were carried out. These included an assessment of alcohol intake and measurements of serum $\gamma$ glutamyltransferase, the percentage saturation of transferrin, and HLA-A,-B,-C, and -DR loci typing on the subjects as well as their families. Liver biopsies wereo performed on some affected subjects.

Of the original 16 index subjects, four were diagnosed as homozygous for the HLA linked irono loading gene which is responsible for the clinical disease idiopathic haemochromatosis. Sixळ appeared to be heterozygotes, three were heterozygotes who were also abusing alcohol, and two did not fit into any of the diagnostic groups. The calculated gene frequency was 0.082 , with an expected heterozygote frequency of $0 \cdot 148$. The fact that no females were identified in the study? suggested that the diagnostic criteria for homozygosity (serum ferritin $>400 \mu \mathrm{g} / \mathrm{l}$ and \%ㅁ. saturation $>60 \%$ ) were set too high. The data were therefore recalculated for the 300 males when this was done the gene frequency was $0 \cdot 115$ and the heterozygote frequency $0 \cdot 204$.

Two subjects were diagnosed as homozygotes in the study of family members and 37 asं heterozygotes (33 definite and four probable). Both the homozygotes and nine of the heterozygotes showed mild to moderate disturbances of iron metabolism. There was considerable overlap between the phenotypic expression in these nine heterozygotes and the homozygotes 0 probably as a result of setting the threshold for the serum ferritin concentration at the relatively? high value of $400 \mu \mathrm{g} / \mathrm{l}$. By doing this a small subset of heterozygotes with biochemicabo abnormalities was identified.

The results of the present pilot study suggest a high frequency of the HLA linked iron loading gene in the Afrikaner population of the South Western Cape.

Idiopathic haemochromatosis (IHC) has been shown in recent years to be inherited as an autosomal recessive disorder, with the susceptibility locus on chromosome 6 in close proximity to the HLA-A locus. ${ }^{1-5}$ The locus is strongly associated with HLA-A3 and B7 in all geographical areas studied and with HLA-A3 and B14 in France,

Received for publication 22 April 1986.

Revised version accepted for publication 3 September 1986.
Australia, and probably England. ${ }^{\circ}$ IHC was pre을 viously considered to be a relatively rare disorder, ${ }^{7-80}$ but recent studies which have exploited HLA datad suggest that the gene frequency in Caucasoids is between 0.05 and 0.09 , with a heterozygote frequency of 10 to $16 \%$ and a disease frequency of between 3 and 8 per $1000 .^{10-25}$ While these figures? were mostly derived from the study of patients witho the clinically manifest disease and affected familyo 
members, there are four investigations in which a similar high prevalence rate has been shown in Caucasoids using epidemiological screening. ${ }^{20} 212425$ The ability to detect subjects who are homozygous for the HLA linked iron loading gene using these new approaches has led to the realisation that the pattern of clinical manifestation is often considerably less severe than was apparent from previous clinical studies. ${ }^{26}$ Many homozygous persons are asymptomatic and the classic triad of hepatomegaly, skin pigmentation, and diabetes mellitus is uncommon. 5111826

If the potentially lethal HLA linked iron loading gene is as prevalent as the current evidence suggests, then concerted attempts should be made in epidemiological surveys to identify asymptomatic homozygotes by applying screening tests with a high sensitivity and predictive accuracy. In this regard, the percentage transferrin saturation and the serum ferritin concentration are of particular value. The transferrin saturation is high in the majority of affected adults, irrespective of the degree of iron overload, ${ }^{17}$ while the serum ferritin concentration bears a linear relationship with the total stores of iron in the body ${ }^{9}$ 27-29 and can therefore be used to identify subjects with iron overload. ${ }^{592021}$ Serum ferritin concentrations are, however, often inappropriately raised in liver disease, leukaemias, lymphomas, cancers, and inflammatory conditions, ${ }^{28}{ }^{30}$ but most of these diseases would have little impact on the results of epidemiological screening studies carried out on apparently healthy subjects in western countries. The one exception is alcoholic liver disease. The serum ferritin concentration has been shown to be significantly raised after excessive alcohol consumption ${ }^{31} 32$ and this might be expected to interfere with the specificity of the test. The problem can, however, be largely overcome if the level of serum $\gamma$ glutamyltransferase $(\gamma \mathrm{GT})$ is measured in subjects with raised ferritin levels, since we have shown that a serum ferritin concentration above $300 \mu \mathrm{g} / \mathrm{l}$ is very unlikely to be the result of alcohol induced hepatic damage if the $\gamma \mathrm{GT}$ is less than $50 \mathrm{U} / 1 .{ }^{32}$ In the present study the serum ferritin and $\gamma$ GT were used in an attempt to determine the frequency of the IHC gene in a predominantly Afrikaner population living in three districts in the South Western Cape. The percentage transferrin saturation was not measured in the initial screening because of the very small quantities of serum available.

\section{Materials and methods}

STUDY POPULATION

During the first half of 1979 a community coronary risk factor survey (CORIS) was carried out in three South Western Cape Province districts, all of which were within 200 miles of Cape Town. ${ }^{33}$ More than $90 \%$ of the white inhabitants in this area are Afrikaans speaking. A group of 7188 Caucasoids was studied, of which 3357 were male and 3831 were female. A subgroup of 599 subjects was then randomly selected for the present prevalence study. The subgroup, which was stratified according to sex and to 10 yearly age intervals (range 15 to 64 years), was made up of 300 males and 299 females. Blood samples which had been frozen at $-20^{\circ} \mathrm{C}$ when the original study was done were sent to our laboratory in Johannesburg for serum ferritin estimations. An arbitrary serum ferritin concentration of $400 \mu \mathrm{g} / \mathrm{l}$ or greater was chosen to identify subjects with iron overload. Concentrations of $\gamma \mathrm{GT}$, serum iron, and total iron binding capacity (TIBC) were then measured in those with raised serum ferritin concentrations. Three years later, in 1982, a second sample was collected from most of the subjects with initially raised serum ferritin concentrations and all the tests were repeated. At the time of the second blood sampling special note was taken of the daily alcohol intake, the use of iron tablets, and a history of blood donation or porphyria. The subjects were more extensively investigated at the end of 1983 and in July 1984. Their available first and second degree relatives were clinically examined for manifestations of IHC, with special attention being directed to the sibs of identified subjects. Blood samples were collected for HLA typing and for $\gamma \mathrm{GT}$, serum iron, TIBC, and serum ferritin. After obtaining informed consent, liver biopsies were performed on 12 subjects in whom biochemical derangements were such that the homozgyous form of IHC was strongly suspected or where homozygotes could not be differentiated from heterozygotes.

\section{Methods}

\section{TECHNIQUES}

The serum iron concentration and TIBC were performed according to the recommendations of the International Committee for Standardization in Haematology. ${ }^{34} 35$ Serum ferritin concentrations were measured by an enzyme linked immunoabsorbent assay, ${ }^{36}$ while the serum $\gamma$ GT was estimated by the method of Persijn and Van der Silk. ${ }^{37}$ HLA-ABC typing of T lymhocytes was carried out using the technique described by Terasaki et $^{3 l^{38}}$ and HLA-DR typing of B lymphocytes by that of Bodmer et al. ${ }^{39}$ The B lymphocytes were isolated by a thrombin nylon wool method described by Danilovs et $a l .{ }^{40}$ The amount of iron present in liver biopsy specimens stained with Prussian blue was assessed 
using previously described criteria ${ }^{41}$ and the nonhaem iron concentrations were measured by the method of Torrance and Bothwell. ${ }^{42}$

\section{DIAGNOSTIC GROUPS}

We attempted to assign the 16 subjects with initial serum ferritin concentrations $>400 \mu \mathrm{g} / \mathrm{l}$ to five diagnostic groups on the basis of the percentage transferrin saturation and $\gamma \mathrm{GT}$. The groups were as follows: (a) probable homozygotes when the transferrin saturation was greater than $60 \%$ and the $\gamma \mathrm{GT}$ less than $50 \mathrm{U} / \mathrm{l}$; (b) probable heterozygotes when the transferrin saturation was less than $60 \%$ and the $\gamma \mathrm{GT}$ was less than $50 \mathrm{U} / \mathrm{l}$; (c) alcohol abusers when the transferrin saturation was less than $60 \%$ and the $\gamma \mathrm{GT}$ greater than $50 \mathrm{U} / \mathrm{l}$; (d) a mixed group of subjects with criteria of both iron overload and alcohol abuse; and (e) a non-diagnosable group in which subjects were included who could not be fitted into the other groups.

\section{GENOTYPE ASSIGNMENT}

Brothers and sisters of an affected homozygote who possessed the same haplotypes were designated homozygous affected $(\mathrm{HH})$. Sibs, parents, and offspring with one haplotype in common with the homozygote were considered heterozygous (HO). Other relatives with neither haplotype in common were considered to be homozygous normal $(\mathrm{OO})$.

\section{Results}

SERUM FERRITIN CONCENTRATIONS IN THE STUDY POPULATION

The serum ferritin values of the 300 male subjects were compared to those obtained in 299 females using analysis of covariance, with age as the covariate. The levels were significantly greater among the male group $(\mathrm{F} 76 \cdot 5, \mathrm{p}<0 \cdot 0001)$. In order to examine this difference more closely the results of the serum ferritin determinations were grouped into 10 yearly age intervals from 15 to 64 years. The geometric means and standard deviation ranges for males and females are shown in the figure. Comparisons at each age interval showed this difference to be present and highly significant in all but the youngest and oldest age groups $(p<0.001$ for all intervals between 20 and 59 years).

\section{SERUM FERRITIN CONCENTRATIONS GREATER} THAN 400 $\mu \mathrm{g} / 1$

Four subjects were regarded as homozygotes on the basis of the transferrin saturation and serum ferritin concentrations as defined previously (table 1). The serum ferritin concentration remained fairly constant in case 1 (table 1) over the period of observation but rose in two others (cases 2 and $\stackrel{\mathbb{2}}{3 ;}$ table 1). The fourth homozygote (case 4 , table 1 䞸 was found to have been diagnosed as having IHS several years previously and had undergone repeatef venesections. The raised $\gamma \mathrm{GT}$ in this subject suggested that alcohol abuse may have contribute to the marked rise in the serum ferritin concentra? tions between 1979 and 1984 . With the exception of this subject, none of the others showed any clinica $\$$ manifestations of IHC. Liver biopsies were per $=$ formed on two of these homozygotes and hepati⿸户 iron concentrations were found to be mildly raise in case 1 and moderately raised in case 2 (table 26 the figures obtained suggesting hepatic iron loads of about 1.5 and $4.5 \mathrm{~g}$, respectively. The presence o o increased iron stores of about two to three times normal was confirmed in the third subject (case 300 by submitting him to repeated venesections.

The seven subjects regarded as heterozygotes. (cases 5 to 11 in table 1 and index subjects in table 39 were all clinically normal. Serum ferritin concentra tions rose progressively over the period of observation in six of them (cases 5 to 10) with the mea ${ }^{\circ}$ rise being about $50 \%$ (table 1 ). A marked rise in the seventh (case 11) to $3200 \mu \mathrm{g} / \mathrm{l}$ was probably attribur table to concomitant alcohol abuse. Liver biopsies were performed on six of the subjects and ab showed increased concentrations of non-haem irof which were in the same range $( \pm 1000 \mu \mathrm{g} / \mathrm{g})$ as thos 8 noted in the homozygotes (table 3). Liver architecture was normal, except for some fatty changes ig two (cases 10 and 11).

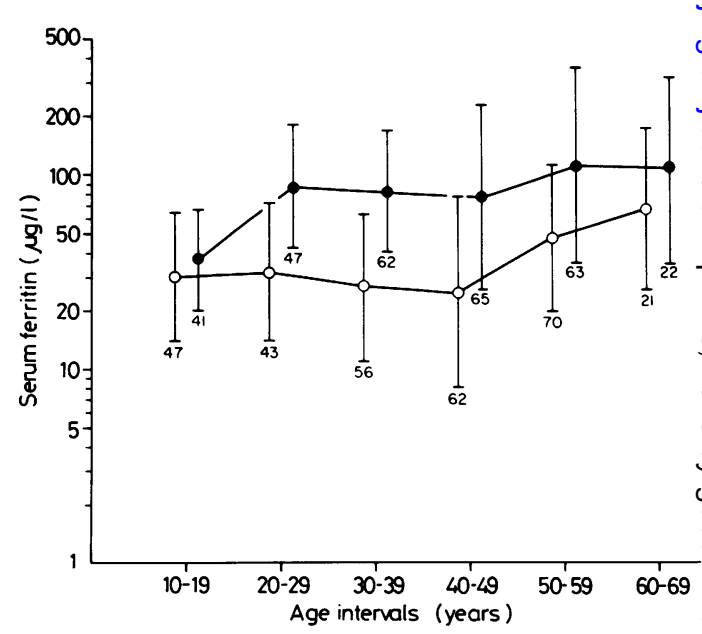

FIGURE Geometric mean ( $S D$ ) serum ferritin concentrations at different age intervals in 300 males (close circles) and 299 females (open circles). The numbers in eac age interval are also shown. 
TABLE 1 Follow up data on the 16 subjects found to have serum ferritin concentrations above $400 \mu \mathrm{g} / \mathrm{l}$. They have been assigned to tentative diagnostic groups based on criteria given in the text (see Materials and methods).

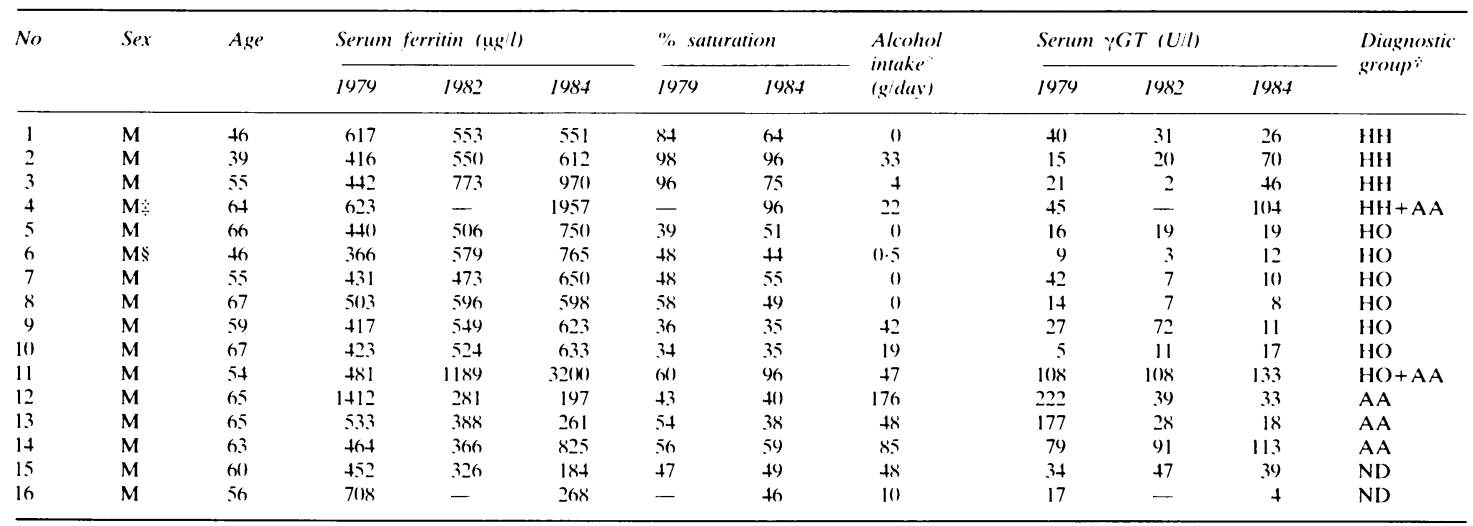

Based on questionnatire in 1979

$+\mathrm{HH}=$ homozygous. $\mathrm{HO}=$ heterozygous. $A \mathrm{~A}=$ heterozygous +alcohol abuse. $\mathrm{ND}=$ non-diagnostic.

Known IHC who had heen extensively venexected several vears previously.

SOriginal serum ferritin was $>4(x) \mu g / l$ hut on retesting was $366 \mu \mathrm{g} / \mathrm{l}$.

TABLE 2 Biochemical (1984 figures), histological, and HLA data on the four homozygous subjects who were found in the epidemiological survey and on two further subjects identified in the family study. (The numbers assigned to family members are those of the related index subjects.)

\begin{tabular}{|c|c|c|c|c|c|c|c|c|c|}
\hline \multirow{2}{*}{$\begin{array}{l}\text { Family } \\
\text { No }\end{array}$} & \multirow[t]{2}{*}{ Age } & \multirow[t]{2}{*}{$\operatorname{sex}$} & \multirow[t]{2}{*}{ HLA haplompe } & \multirow[t]{2}{*}{$\%$ saturation } & \multirow{2}{*}{$\begin{array}{l}\text { Sorum } \\
\text { forritin } \\
\text { fug/l) }\end{array}$} & \multirow{2}{*}{$\begin{array}{l}\text { Scrum } \\
\because(; T \\
(U / l)\end{array}$} & \multicolumn{2}{|c|}{ Hepatic histology } & \multirow{2}{*}{$\begin{array}{l}\text { Hepatic iron } \\
\text { lugh/g wet weightl) }\end{array}$} \\
\hline & & & & & & & $\begin{array}{l}\operatorname{lr}(m) \\
(0-t)\end{array}$ & $\begin{array}{l}\text { Fanty } \\
\text { changes }\end{array}$ & \\
\hline \multicolumn{10}{|c|}{ Index subjects } \\
\hline 1 & th & $\mathbf{M}$ & $\begin{array}{l}A w 24(9) \cdot B 7 \cdot(w 7 . D R 2: \\
A w 24(9) \cdot B w 39(16) \cdot\left(w_{3} \cdot D R 2\right.\end{array}$ & 64 & 5 & 26 & $2+$ & & 1142 \\
\hline 2 & 39 & $\mathbf{M}$ & $\begin{array}{l}A w 24(9) . B w 39(16) .(w 3 . D R w h \\
A 2 . B w+4(12) .(1 w-. D R 1\end{array}$ & 96 & 612 & 70 & $1.5+$ & & 3074 \\
\hline 3 & 55 & $\mathbf{M}$ & $\begin{array}{l}\text { A.3.B7.( (w7.1)R2 } \\
\text { A.3.B7.( (w7.1)R2 }\end{array}$ & 75 & 976 & th & - & - & - \\
\hline $4 \div$ & ht & M & $\begin{array}{l}\text { A2.B3.5.(w4.1)Rw6 } \\
\text { A1.B7.(w7.I)R7 }\end{array}$ & 96 & 1057 & 105 & - & - & - \\
\hline \multicolumn{10}{|c|}{ Family members } \\
\hline 2 & $2 x$ & $\mathrm{~F}$ & $\begin{array}{l}A w 2+(9) \cdot B w \cdot 39(16) \cdot(w \cdot 3.1) R w 6 \\
A 2 . B w+4(12) \cdot(w-. D R I\end{array}$ & 76 & 217 & & - & - & - \\
\hline 8 & $2 x$ & M & $\begin{array}{l}A 2 . B+4(12) \cdot(-.1) R 1 \\
A 2 . B w 57(17) .(w 6.1) R 7\end{array}$ & 75 & 598 & & $1 \cdot 5+$ & & 1046 \\
\hline
\end{tabular}

Upper limit of normal $\pm 350 \mathrm{\mu g} / \mathrm{g}$.

Kknown IHC who had heen extensively venesected previously

The index casc was diagnosed as a heterozygote (sec table 3).

The alcohol abusers were characterised by concomitant changes in the serum ferritin and $\gamma \mathrm{GT}$ concentrations (table 1). For example, in one (case 12) a drop in the serum ferritin concentration from 1412 to $197 \mu \mathrm{g} / \mathrm{l}$ was paralleled by a drop in the $\gamma \mathrm{GT}$ from 222 to $33 \mathrm{U} / \mathrm{l}$. It was not possible to assign the last two subjects (cases 15 and 16, table 1) to any of the diagnostic groups.

FAMILY STUDIES

In all, a total of 87 relatives of identified homo- zygotes was examined and two homozygotes were diagnosed on the basis of chemical findings and HLA markers (table 2). The one in family 2 was the 28 year old sister of an identified homozygote. She had a transferrin saturation of $85 \%$ but no increase in the serum ferritin concentration. The other subject was a 28 year old male in family 8 , whose father had been diagnosed as a heterozygote. The fact that the 28 year old son had a transferrin saturation of $75 \%$ and a serum ferritin concentration of $596 \mu \mathrm{g} / \mathrm{l}$ suggested that he was a homozygote, in 
TABLE 3 Biochemical, histological, and HLA data on the seven heterozygous subjects who were found in the epidemiological survey and on other probable heterozygotes identified in the family study. (The numbers assigned to famil $\overrightarrow{\mathrm{C}^{\prime}}$ members are those of the related index subjects.)

\begin{tabular}{|c|c|c|c|c|c|c|c|c|c|}
\hline \multirow{2}{*}{$\begin{array}{l}\text { Family } \\
\text { No }\end{array}$} & \multirow[t]{2}{*}{ Age } & \multirow[t]{2}{*}{ Sex } & \multirow[t]{2}{*}{ HLA haplotype } & \multirow[t]{2}{*}{$\%$ saturation } & \multirow{2}{*}{$\begin{array}{l}\text { Serum } \\
\text { ferritin } \\
(\mu \mathrm{g} / \mathrm{l})\end{array}$} & \multirow{2}{*}{$\begin{array}{l}\text { Serum } \\
\gamma G T \\
(U / l)\end{array}$} & \multicolumn{2}{|c|}{ Hepatic histology } & \multirow{2}{*}{$\begin{array}{l}\text { Hepatic iron } \\
\text { lug/g wet weigh }\end{array}$} \\
\hline & & & & & & & $\begin{array}{l}\text { Iron } \\
(0-4)\end{array}$ & $\begin{array}{l}\text { Fatty } \\
\text { changes }\end{array}$ & \\
\hline
\end{tabular}

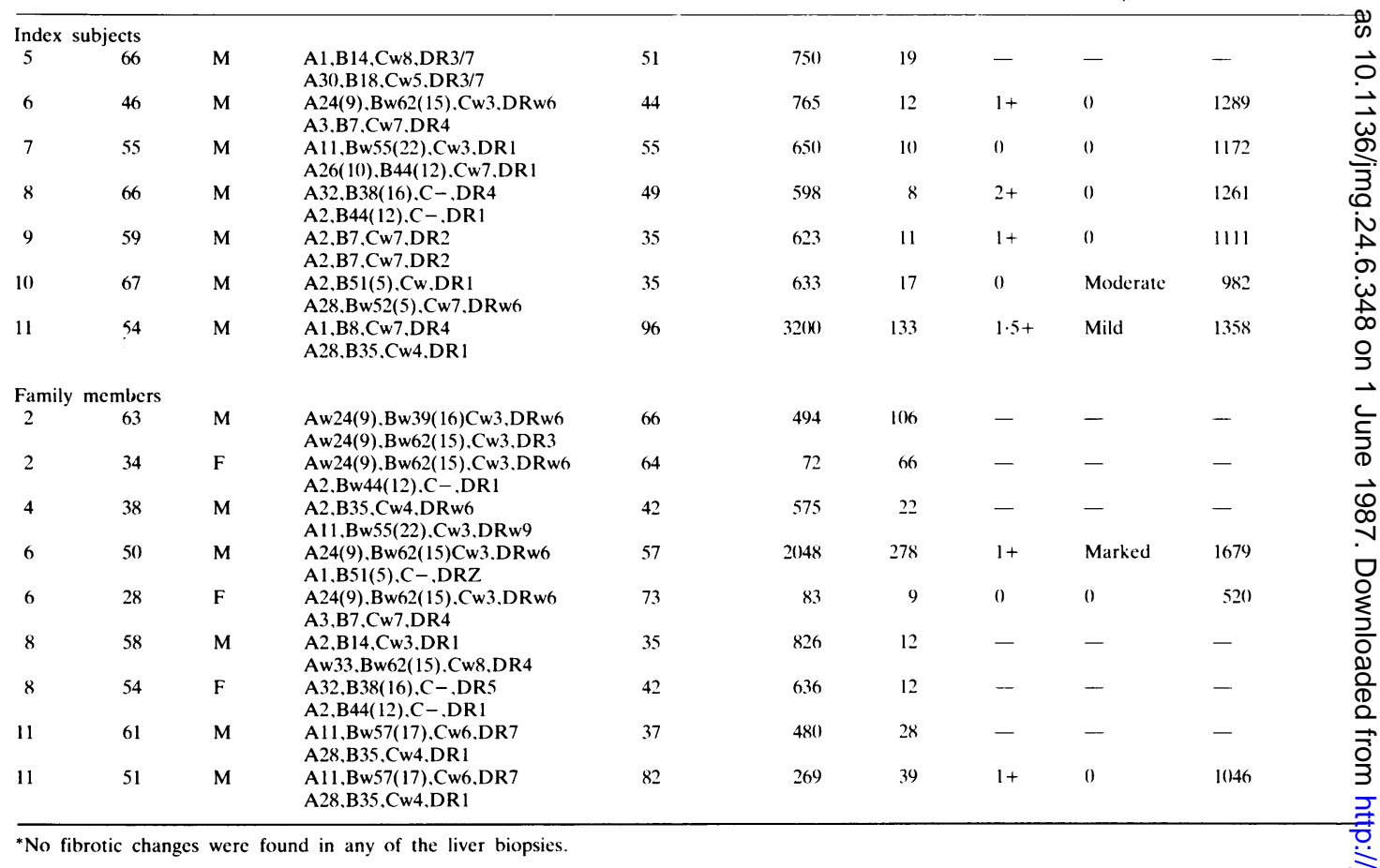

which case his mother must also have been carrying the HLA linked iron loading gene or determinant. Liver biopsy in the son revealed a hepatic iron concentration of $1046 \mu \mathrm{g} / \mathrm{g}$ (table 2) which is two to three times normal.

Thirty-three family members out of the 87 relatives tested were diagnosed as definite heterozygotes on the basis of genotype assessment. Fourteen were female and 19 male. Their mean age was 42 years (range 16 to 83). In addition, four subjects, all of whom were males, were diagnosed as probable heterozygotes. Three shared one haplotype with an index case and showed disturbances of iron metabolism, while one (in family 8 ) only had a biochemical abnormality (serum ferritin $826 \mu \mathrm{g} / \mathrm{l}$ ). Nine of these heterozygous subjects (five definite and four probable) had abnormalities in iron metabolism, which are itemised in table 3. Table 3 also includes HLA data and some hepatic histological findings on them and the original seven index heterozygotes. Liver biopsies were carried out in only three of the ascertained relatives from familie 6 and 11 . There was a mild increase in iron stores the two males, while the hepatic iron concentration was at the upper limit of normal in the female. The highest value was obtained in a subject (family कु who appeared to be abusing alcohol (serum ferritim $2048 \mu \mathrm{g} / \mathrm{l}$, serum $\gamma \mathrm{GT} 278 \mathrm{U} / \mathrm{l})$.

\section{HLA TYPING}

In terms of HLA typing, one of the four homo zygotes had the haplotype HLA-A3B7 from bo parents, while two others who had inherited $B$ P without A3 via one chromosome were heterozygow for B7 alone (table 2). As far as the seve heterozygous index subjects were concerned, on was heterozygous for the HLA-A3B7 haplotype and another was homozygous for HLA-B7 (table 3).

\section{GENE FREQUENCY}

Assuming that all the IHC homozygotes in the sample of 599 were ascertained, the frequency of the 
gene for IHC is $0 \cdot 082(\mathrm{SE} 0 \cdot 020)$ given as the square root of the homozygote frequency. On the basis of this gene frequency and according to HardyWeinberg expectation, the proportion of heterozygotes in the population would be $0 \cdot 148$ or nearly 1 in 6. It was noteworthy, however, that all the subjects in the study who showed phenotypic abnormalities were males, suggesting that the serum ferritin cut-off point of $400 \mu \mathrm{g} / \mathrm{l}$ was too high to identify affected females. If the gene frequency is calculated using only the male population of 300 the frequency of the IHC gene becomes $0 \cdot 115$ (SE 0.029) and the expected heterozygote frequency 0.204 or 1 in 5 .

\section{Discussion}

There is currently much interest in the early detection of subjects homozygous for the HLA linked iron loading gene that can lead to clinical IHC, ${ }^{10-25}$ since intensive venesection therapy can prevent the development of organ damage such as cirrhosis. ${ }^{26}$ Out of the various epidemiological data that have been collected has come the realisation that the clinical spectrum of IHC is much wider than was previously appreciated. At one end is the fully developed disease, with skin pigmentation, cirrhosis, diabetes, and other manifestations of organ damage, while at the other there are subjects, usually females, with little or no clinical or biochemical evidence of increased body iron. In between, lie the majority of subjects, who show varying degrees of iron overload. ${ }^{26}$ Most of our knowledge on the phenotypic expression in affected homozygotes and heterozygotes has been derived from family studies in which affected subjects have been identified on the basis of HLA typing. ${ }^{5} 111743-46$ In such studies it has been found that most heterozygotes can be identified among the relatives of iron loaded homozygotes only by inference. While the mean values for the various laboratory tests of iron metabolism have been found to be somewhat higher than normal in such heterozygotes, they tend to be closer to normal values than to those found in homozygotes.

These points have been raised in order to underline the difficulties that might be anticipated in interpreting the results obtained in any epidemiological study in which the starting point is the population at large and not clinically affected homozygotes. In this regard, there are two tests that have been shown to be of value, namely the percentage transferrin saturation and the serum ferritin concentration. The first is raised in homozygous IHC adults irrespective of the size of the body iron stores, ${ }^{44}$ while the second mirrors the size of these stores. ${ }^{9}$ Their predictive accuracy in identifying phenotypic expression in affected genotypes is obviously affected by variables which affect iron nutrition, such as age, sex, child bearing, and menstruation. Their specificity and sensitivity are also affected by the arbitrary threshold values which are chosen. In one family study a threshold value of $62 \%$ for transferrin saturation was found by discriminant analysis to have a predictive accuracy of $92 \%$ for homozygotes, while a raised serum ferritin concentration after logarithmic transformation had a predictive accuracy of only $71 \% .{ }^{44}$ However, other workers have reported a normal transferrin saturation in $25 \%$ of subjects with iron overload. ${ }^{46}{ }^{47}$ In addition, Bassett et $\mathrm{l}^{\text {th }}$ found that the serum ferritin concentration is useful in the early detection of the IHC gene and has a slightly higher predictive accuracy than the transferrin saturation in screening young adults for IHC. In passing, it should be mentioned that two families have been described in which the serum ferritin was found to be normal in a number of members despite increased iron stores, ${ }^{48}$ but this seems to be rare, occurring in no more than $5 \%$ of affected families. ${ }^{49}$

Because both tests are useful they have been combined in various ways in the four epidemiological studies that have been reported to date (table 4). ${ }^{2021} 2425$ While comparison of the results in Canada, Sweden, and the United Kingdom are complicated by variations in the criteria that were used, the conclusions were very similar. Estimates of the number of homozygotes in the communities studied were high, with frequencies varying between 0.24 and $0.5 \%$.

In the present study a somewhat different approach was dictated by the fact that only very small volumes of serum were initially available for analysis. This meant that it was possible to measure the serum ferritin concentration but not the serum iron and total iron binding capacity. We chose a comparatively high arbitrary threshold value for the serum ferritin of $400 \mu \mathrm{g} / \mathrm{l}$ because we anticipated that minor rises would often be the result of alcohol abuse and not of iron overload. ${ }^{31}{ }^{32}$ In all, 17 male subjects were identified in this way. At the outset it was realised that there are inherent dangers in using a continuously varying measure such as the serum ferritin concentration to identify homozygous IHC subjects. For this reason additional information was sought on each of those identified as having a raised serum ferritin concentration. Firstly, serum ferritin concentration was measured on a further two occasions over the following five years in all except the one subject who had died. Secondly, alcohol abuse was identified by direct questioning and repeated $\gamma \mathrm{GT}$ estimations. Thirdly, the transferrin 
TABLE 4 The results of four epidemiological surveys designed to ascertain the prevalence of the HLA linked iron loading gene in different populations.

\begin{tabular}{|c|c|c|c|c|c|c|}
\hline \multirow[t]{2}{*}{ Country } & \multirow{2}{*}{$\begin{array}{l}\text { No of } \\
\text { subjects }\end{array}$} & \multirow{2}{*}{$\begin{array}{l}\text { Age range } \\
(y)\end{array}$} & \multirow[t]{2}{*}{ Screening criteria } & \multicolumn{2}{|c|}{ Abnormal findings } & \multirow{2}{*}{$\begin{array}{l}\text { Estimated } \\
\text { disease frequency } \\
(\%)\end{array}$} \\
\hline & & & & $\begin{array}{l}\text { No of } \\
\text { subjects }\end{array}$ & $\begin{array}{l}\text { Assigned } \\
\text { genotype* }\end{array}$ & \\
\hline Canada ${ }^{24}$ & 1105 & $1-90$ & $\%$ saturation $>55 \%$, serum ferritin $>90$ th centile & 6 & $\begin{array}{ll}3 \mathrm{HH} \\
3 \mathrm{HO}\end{array}$ & $0 \cdot 27$ \\
\hline Sweden 211 & $\begin{array}{l}718 \\
\text { (males) }\end{array}$ & $30-39$ & $\%$ saturation $>58 \%$, serum ferritin $>164 \mu \mathrm{g} / \mathrm{l}$ & 9 & $3 \mathrm{HH}$ & $0 \cdot 5$ \\
\hline Sweden 21 & 8750 & $?$ & $\begin{array}{l}\% \text { saturation }>70 \% \text {. serum ferritin }>200 \mu \mathrm{g} / \mathrm{l} \text {. } \\
\text { desferrioxamine excretion }>1.5 \mathrm{mg} / 24 \mathrm{~h}\end{array}$ & 14 & $14 \mathrm{HH}$ & $0 \cdot 24$ \\
\hline United Kingdom ${ }^{25}$ & 1800 & $?$ & $\begin{array}{l}\% \text { saturation }>48 \% \text {, serum iron }>35 \mu \mathrm{mol} / \mathrm{l} \text {, } \\
\text { serum ferritin }>200 \mu \mathrm{g} / \mathrm{l}\end{array}$ & $?$ & $5 \mathrm{HH}$ & $0 \cdot 3$ \\
\hline
\end{tabular}

${ }^{*} \mathrm{HH}=$ homozygote. $\mathrm{HO}=$ heterozygote.

saturation, a sensitive measure of homozygosity in adults, ${ }^{44}$ was estimated on at least two occasions. Finally, the subjects were evaluated clinically to exclude intercurrent illness.

Subjects with raised ferritin concentrations were assigned to one of several categories, the most important of which were homozygosity, heterozygosity, alcohol abuse, and a combination of alcohol abuse plus one of the other categories. Eleven subjects, four homozygotes and seven heterozygotes, were diagnosed in the initial survey as carrying the HLA linked iron loading gene and a further two homozygotes and 37 heterozygotes (33 definite and four probable) were diagnosed in studies on the families of affected subjects. The distinction between homozygosity and heterozygosity was based on the transferrin saturation, since the ferritin concentration alone did not discriminate between the two groups. Liver biopsies were done on eight of the index cases and on four of their relatives. The hepatic iron load in homozygotes was moderately raised, as it was in several of the heterozygotes. The fact that phenotypic expression in subjects identified as homozygotes was so similar to that in some heterozygotes may well be due to the fact that the threshold value for the serum ferritin concentration was set at the relatively high value of $400 \mu \mathrm{g} / \mathrm{l}$. This approach would be expected to identify a small subset of heterozygotes with biochemical abnormalities overlapping with a mild asymptomatic homozygote population. Some support for this contention is supplied by the data of Bassett et $a l^{50}$ on serum ferritin concentrations in heterozygotes diagnosed in family studies. Fewer than $10 \%$ of male heterozygotes had serum ferritin concentrations greater than $400 \mu \mathrm{g} / \mathrm{l}$. In the same study they noted that there was no tendency for iron to accumulate in the body in heterozygotes followed over a 16 year period. Our own finding of a moderate but progressive rise in the serum concen- trations of all the heterozygous index cases $i$ somewhat surprising and raises the question as to whether the group may have included homozygou? subjects or whether complicating factors such as alcohol abuse were confusing the findings.

Although the numbers are small, no striking increase in the numbers of $\mathrm{A} 3$ containing haplotypes associated with the IHC gene was noted in the present study. Of the 14 haplotypes defined as being associated with the IHC gene (five homozygotes and four heterozygotes), HLA-A allele A3 was presen only twice and this in homozygous form in the indew case in family 3 (table 2). There was no know consanguinity in the parents of this case. The complete haplotype was $\mathrm{A} 3, \mathrm{~B} 7, \mathrm{Cw} 7, \mathrm{DR} 2$ which is $\bar{\Phi}$ classical Caucasoid one, common in the South African white population of the South Wester Cape. The B7,Cw7,DR2 part of the haplotype was:however, found in association with the IHC gene i $\overline{\bar{P}}$ three other cases, twice with A2 and once witi A24(9) (tables 2 and 3). These haplotypes could we have resulted from a crossover between the $A$ locus and the IHC gene, C locus, B locus, D locus containing segment. Whether such a crossover occurred before or after the settling of the Cape by the Europeans is not possible to say.

In setting rigid criteria for the diagnosis ofhomozygotes in the present study we aimed a defining the minimum rather than the real genes frequency for the HLA linked iron loading gene is the Afrikaner population we were sampling. The calculated gene frequency of 0.082 is comparable the estimated gene frequency of 0.088 is Australians. ${ }^{50}$ Phenotypic expression might also b expected to be similar, since both populations have a high meat consumption. By setting a high serum ferritin threshold no females were identified in the initial screen. In addition, the inclusion of subject in the 15 to 19 year old age group further reduced the likelihood of phenotypic expression in affecte 
genotypes. On this basis, there seemed some justification for recalculating the gene frequency using the male sample of 300 . When this was done, the very high figure of $0 \cdot 115$ was obtained. It should be noted that there are several genetic disorders, including porphyria variegata and familial hypercholesterolaemia, which occur with unusually high frequency in the Afrikaner population, ${ }^{51} 52$ and the present findings suggest that further, more detailed, studies should be done to find out whether IHC is another such condition. However, the demonstration that the IHC gene is not linked in the cis position to one particular HLA haplotype makes it very unlikely that its high frequency in the Afrikaner population is due to founder effect. In fact, among the five randomly ascertained IHC homozygotes no fewer than nine different haplotypes were found to be associated with the IHC gene. If the HLA-A and $B$ loci are considered, then eight different haplotypes were evident. From these results it can be inferred that the IHC gene had already attained its high frequency in the populations of Holland. Germany, and France before 1652, the year in which the European settlement at the Cape began, and that it was introduced into the local population by a number of persons possibly at different times.

The fact that the estimated frequency of the IHC gene in the Afrikaner population is no higher than that found in other Caucasoid populations 20212425 suggests that there has not been any significant IHC gene flow into this population since settling in South Africa. In this regard, it is of note that the iron overload which is so common in the local black population is the result of dietary contamination ${ }^{53}$ and its prevalence and severity in urban communities is declining rapidly with changing drinking patterns. ${ }^{54}$

\section{References}

' Simon M. Bourel M. Genetet B. Fauchet R. Idiopathic hemochromatosis: demonstration of recessive transmission and early detection by family HLA typing. $N$ lingl $J$ Med 1977:297:1017-21.

2 Bothwell TH. Charlton RW. A general approach to the problems of iron deficiency and iron overload in the population at large. Semin Hematol 1982:19:54-67.

Bomford A. Eddleston AL. Kennedy LA. Batchelor JR. Williams R. Histocompatability antigens as markers of abnormal iron metabolism in patients with idiopathic hacmochromatosis and their relatives. Lancet 1977:i:327-9.

+ Kravitz K. Skolnick M. Edwards C. et al. Pedigree analysis of the linkage between HLA and hemochromatesis. In: Morton NE. Chung CS. eds. Genetic epidemiology. New York: Academic Press. 1978:241-6.

Cartwright GE. Edwards CQ. Kravitz K. et al. Hereditary hemochromatosis: phenotypic expression of the discase. N Engl J Med 1979:301:175-9.

"Simon M. Alexandre JL. Ratuchet R. Genetet B. Bourel M. The genetucs of hemochromatosis. Prog Med Genet 1980:4:135-68. Finch SC. Finch CA. Idiopathic hemochromatosis, an iron storage disease. Iron metabolism in hemochromatosis. Medicine 1955:34:381-430.

* Saddi R. Fcingold J. Idiopathic hacmochromatosis: an autosomal recessive disease. Clin Genet 1974:5:23+41.

"Bothwell TH. Charlton RW. Cook JD. Finch CA. Iron metabolism in man. Oxford: Blackwell Scientific Publications. 1979:121-55

1" Beaumont C. Simon M. Fauchet R. et al. Serum ferritin as a possible marker of hemochromatosis allele. $N$ Engl $J$ Med 1979:301:169-79.

"Edwards CQ. Cartwright GE. Skolnick MH. Amos DB. Homozygosity for hemochromatosis: clinical manifestations. Ann Intern Med 1980:93:519-25.

12 Simon M. Alexandre JL. Bourel M. LeMarec B. Scordia C. Heredity of idiopathic hacmochromatosis: a study of 106 families. Clin Genet 1977:11:327-41.

1. Lipinski M. Hors J. Saleun JP. et al. Idiopathic hemochromatosis: linkage with HLA. Tissue Antigens 1978:11:471-4

${ }^{1+}$ Beaumont C. Simon M. Fauchet R. et al. Serum ferritin as a possible marker of the hemochromatosis allele. $N$ Engl J Med 1979:301:169-74.

15 Kidd KK. Genetic linkage and hemochromatosis. N Eingl J Med 1979:301:2(1)-10.

16 Simon M. Fauchet R. Hespel JP. et al. Idiopathic hemochromatosis: a study of biochemical expression in 247 heterozygous members of 63 families: evidence for a single major HLA-linked gene. Gastroenterology 1980:78:7(13-8.

17 Dadone MM. Kushner JP. Edwards CQ. Bishop DT. Skolnick MH. Hereditary hemochromatosis. Analysis of laboratory expression of the disease by genotype in 18 pedigrees. A $m \mathrm{~J}$ ( Clin Pathol 1982:78:196-207.

is Borwein ST. Ghent CN. Flanagan PR. Chamberlain MJ. Valberg LS. Genetic and phenotypic expression of hemochromatosis in Canadians. (lin Invest Med 1983:6:171-9.

1" Simon M. Bourel M. Genetet B. Fauchet R. Idiopathic hemochromatosis: demonstration of recessive transmission and carly detection by family HLA typing. $N$ lingl $J$ Med 1977:297:1017-21.

"I Olsson KS. Ritter B. Rosen U. Heedman PA. Staugard F. Prevalence of iron overload in eentral Sweden. Actu Med Scand 1983:213:145-50.

$\Rightarrow$ Olsson KS. Eriksson K. Ritter B. Hecdman PA. Screening for iron overload using transferrin saturation. Acta Med Scand $1984: 215: 105-12$.

II Edwards CQ. Skolnick MH. Kushner JP. Hereditary hemochromatosis. Contribution of genetic analyses. In: Brown EB. ed Progress in hematology. New York: Grunc and Stratton. 1981:43-71.

? Bassctt ML. Doran TJ. Halliday JW. Bashir HV. Powell LW. Idiopathic hemochromatosis: demonstration of homozygousheterozygous mating by HLA typing of families. Hum Genet 1982:60):352-6.

2t Valberg LS. Sorhic J. Ludwig J. Pelleticr O. Scrum ferritin and the iron status of Canadians. (an Med Assoc I 1976:114:471-21.

- Tanner AR. Desai S. Lu W. Wright R. Screening for haemochromatosis in the UK: preliminary results. (itut 1985:26: $1139-4(1) \mathrm{A}$

2" Bothwcll TH. Charlton RW, Motulsky AG. Idiopathic hemochromatosis. In: Stanbury JB. Wyngatarden JW. Fredrickson DS. Goldstein JL. Brown MS. eds. The metabolic hasis of inherited disease. 5th ed. Now York: McGraw Hill. 1983: $1269-98$

7 Walters GO. Miller FM. Worwood M. Scrum ferritin concentration and iron stores in normal subjects. J ('lin Pathol 1973:26:77(1)-2.

2x Lipschitz DA. Cook JD. Finch CA. A clinical evaluation of scrum forritin. N Eingl J Med 1974:290:1213-6.

(2) Bezwoda WR. Bothwell TH. Torrance JD. et al. The rela- 
tionship between marrow iron stores, plasma ferritin concentration and iron absorption. Scand J Haematol 1979;22:113-20.

30) Worwood M. Serum ferritin. CRC Crit Rev Clin Lab Sci 1979:10:171-204.

${ }^{31}$ Kirstenson H, Fex G, Trell E. Serum ferritin, gamma-glutamyltransferase and alcohol in healthy middle aged men. Drug Alcohol Depend 1981;8:43-50.

${ }^{32}$ Meyer TE, Kassianides C, Bothwell TH, Green A. Effects of heavy alcohol consumption on serum ferritin concentrations. $S$ Afr Med J 1984;66:573-5.

33 Roussouw JE, Du Plessis JP, Benade AJS, et al. Coronary risk factor screening in three rural communities. Coris baseline study. S Afr Med J 1983;64:430-6.

${ }^{34}$ Expert Panel of the International Committee for Standardization in Haematology. The measurement of total and unsaturated iron-binding capacity in serum. Br J Haematol 1978;38:281-90.

35 Expert Panel of the International Committee for Standardization in Haematology. Recommendations for measurement of serum iron in human blood. Br J Haematol 1978;38:291-4.

36 Conradic JD, Mbhele BEL. Quantitation of serum ferritin by an immunosorbent assay (ELISA). S Afr Med J 1980;57:282-7.

37 Persijn J, van der Silk W. A new method of the determination of gamma-glutamyl transferase in serum. $J$ Clin Chem Clin Biochem 1976:11:421-6.

${ }^{38}$ Teresaki PI, McCelland J, Min Sik Park, McCurdy B. Microdroplet lymphocyte cytotoxicity test. In: Manual of tissue typing techniques. Bethesda: NIH, 1974:67-72.

39 Bodmer JG, Pickbourne P, Richard S. Joint report on Ia serology. In: Histocompatibility testing. Copenhagen: Munksgaard, 1977:35-84.

41 Danilovs JA, Ayoub G, Terasaki PI. B lymhocytes isolation by thrombin-nylon wool. In: Histocompatibility testing. Los Angeles: UCLA Tissue Typing Laboratory, 1980:287-8.

41 Bothwell TH, Bradlow BA. Siderosis in the Bantu. A combined histopathological and chemical study. Arch Pathol 1960;70: 279-92.

42 Torrance JD, Bothwell TH. A simple technique for measuring iron concentrations in formalinised liver samples. $S$ Afr $J$ Med Sci 1968;33:9-11.

${ }^{43}$ Feller ER, Pont A, Wands JR, et al. Familial hemochromatosis. Physiologic studies in the precirrhotic stage of the disease. $N$ Engl J Med 1977;296:1422-6.
44 Dadone MM, Kushner JP, Edwards CQ. Bishop DT, Skolnick MH. Hereditary hemochromatosis: analysis of laboratory ex- $\vec{\equiv}$ pression of the disease genotype in 18 pedigrees. Am J Clin Pathol 1982;78: 191-207.

45 Bassett ML. Haliday JW, Powell LW. HLA typing in idiopathic hemochromatosis: distinction between homozygotes and heter- $\overline{\bar{C}}$ ozygotes with biochemical expression. Hepatology 1981:1: $120-6$.

46 Bassett ML, Halliday JW, Ferris RA, Powell LW. Diagnosis of hemochromatosis: predictive accuracy of biochemical screeninges tests. Gastroenterology 1984;87:628-33.

47 Jacobs A, Miller F. Worwood M, Beamish MR, Wardrop CA. Ferritin in the serum of normal subjects and patients with iron deficiency and iron overload. $\mathrm{Br}$ Med $J$ 1972:4:206-8.

$4 \times$ Wands JR, Rowe JA, Mezcy SE. et al. Normal serum ferritin concentrations in precirrhotic hemochromatosis. $N$ Engl J Med 1976;294:302-5.

49 Halliday JW, Russo AM, Cowlishan JL. Powell LW. Serum $\stackrel{\text { I }}{\AA}$ ferritin in diagnosis of hacmochromatosis. Lancet 1977;ii:621-4. \%)

5) Bassett ML, Doran TJ. Halliday JW, Bashir HV, Powcll LW. $\omega$ Idiopathic hemochromatosis: demonstration of homozygous- $\frac{\vec{\infty}}{\infty}$ heterozygous mating by HLA typing of families. Hum Geneto 1982;60:352-6.

51 Dean G. The porphyrias. 2nd ed. London: Pitman, 1971:1-176. $\rightarrow$

52 Jenkins T, Nicholls E, Gordon E, Mendelsohn D, Seftel HC. $ᄃ$ Andrew MJA. Familial hypcrcholesterolaemia-a common genetic disorder in the Afrikaans population. $S$ Afr Med $J$ 1980:57:943-7.

53 Bothwell TH, Isaacson C. Siderosis in the Bantu. A comparison of the incidence in males and females. Br Med J 1962;i:522-4.

${ }^{54}$ MacPhail AP. Simon MO, Torrance JD, Charlton RW, Bothwell TH, Isaacson C. Changing patterns of dietary iron overload in black South Africans. Am J Clin Nutr 1979;32:1272-8.

Correspondence and requests for reprints to Profes- $\frac{\mathbb{D}}{\square}$ sor T H Bothwell, Department of Medicine, Uni-ô versity of the Witwatersrand Medical School, 73 York Road, Parktown 2193, Johannesburg, South Africa. 